\title{
Palaeogeographical significance of the Eemian biogenic sediments at the Bór site (Warta River valley, central Poland)
}

\author{
Joanna PETERA-ZGANIACZ ${ }^{1, *}$, Ryszard K. BORÓWKA², Jacek FORYSIAK', \\ Grażyna MIOTK-SZPIGANOWICZ ${ }^{3}$ and Dominik PAWŁOWSKI ${ }^{4}$
}

\footnotetext{
1 Department of Geomorphology and Palaeogeography, Institute of Earth Science, Faculty of Geographical Sciences, University of Łódź, Narutowicza 88, 90-139 Łódź, Poland

2 Geology and Palaeogeography Unit, Faculty of Geosciences, Institute of Marine and Coastal Sciences, University of Szczecin, Mickiewicza 18, 70-383 Szczecin, Poland

3 Polish Geological Institute - National Research Institute, Marine Geology Branch, Kościerska 5, 80-328 Gdańsk, Poland

4 Institute of Geology, Adam Mickiewicz University, Maków Polnych 16, 61-606 Poznań, Poland
}

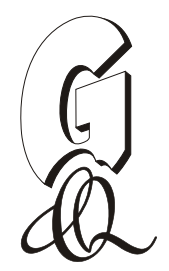

\begin{abstract}
Petera-Zganiacz J., Borówka R. K., Forysiak J., Miot-Szpiganowicz G. and Pawłowski D. (2013) Palaeogeographical significance of the Eemian biogenic sediments at the Bór site (Warta River valley, central Poland). Geological Quarterly, 57 (4): $687-700$, doi: $10.7306 / \mathrm{gq} .1122$

An investigated area is located in the middle reach of the Warta River valley. During drillings in the Bór site organic deposits such as detrital calcareous gyttja and calcareous detrital gyttja has been documented in a depth between 14.9 and $16.6 \mathrm{~m}$. The organic deposits are covered by mineral, mostly sandy deposits. The accumulation took place in the small lake formed as an abandoned channel. Palynological analysis led to the conclusion that biogenic accumulation began at the end of Wartanian and took place at least to the Eemian Interglacial optimum. Results of palynological, Cladocera and geochemical analyses indicate water level changes and the increasing of the trophy status of the reservoir. Presence of Mesozoic substratum very close to the palaeolake bottom influenced significantly the chemical features of the organic deposits. As Eemian organic deposits are uncommon in the Warta River valley, the Bór site seems important for palaeogeographical reconstructions of the Warta River valley during Eemian Interglacial.
\end{abstract}

Key words: gyttja, palynology, Cladocera, geochemistry, Warta River valley deposits.

\section{INTRODUCTION}

In central Poland, there are a lot of well-documented sites of biogenic sediments from the Late Wartanian and Eemian Interglacial (e.g., Klatkowa, 1990; Bruj and Roman, 2007), which are located in the morainic plateau, while not numerous were found in river valleys. This situation provides solid background for the palaeogeographical interpretation of the plateaus, but it does not enable a successful reconstruction of the river valley floors of the period in question.

The data presented is a contribution to the knowledge about the functioning of the river system in central Poland during the Eemian Interglacial. The Vistula drainage system from that period is recognized much better (Marks and Pochocka, 1999; Marks, 2005b) than those known from the Odra and Warta rivers. Most of the information comes from drillings, and palaeogeographical reconstructions are based on analysis of properties of the mineral deposits due to the shortage of organic mate-

\footnotetext{
* Corresponding author, e-mail: jap@geo.uni.lodz.pl
}

Received: March 14, 2013; accepted: August 13, 2013; first published online: October 23, 2013 rial suitable for pollen analysis and reliable dating (Marks, 2005b). For this reason each site, where Eemian Interglacial organic deposits are documented is very important and allow us to verify the interpretation based on mineral material. It is obvious that the sites where age was determined palynologically have the greatest value as presented in this paper Bór site or e.g., Krzyżówki (Noryśkiewicz, 1999), but the mollusc analysis can be also sufficient to confirm Eemian age of fluviolacustrine deposits (e.g., Skompski, 1983; Szałamacha and Skompski, 1999; Meng et al., 2009).

Until recently, the palaeogeography of the middle reach of Warta River valley during Eemian Interglacial was reconstructed on the base of the mineral, mostly sandy deposits (Czarnik, 1972; Trzmiel, 1996). The situation has greatly improved, when lake deposits and peat have been found in the Krzyżówki site, near Koło (Szałamacha and Skompski, 1999) and on the basis of palynological data were determined as belonging to the late glacial of the Wartanian and the Eemian Interglacial (Noryśkiewicz, 1999). Their deposition took place in a shallow lake, perhaps an oxbow lake, which has gradually transformed into a mire. Investigations in the Bór site bring (Fig. 1A, B) new data about the palaeogeography of the meridional section of the Warta River valley close to Uniejów during the Wartanian termination and Eemian Interglacial. 

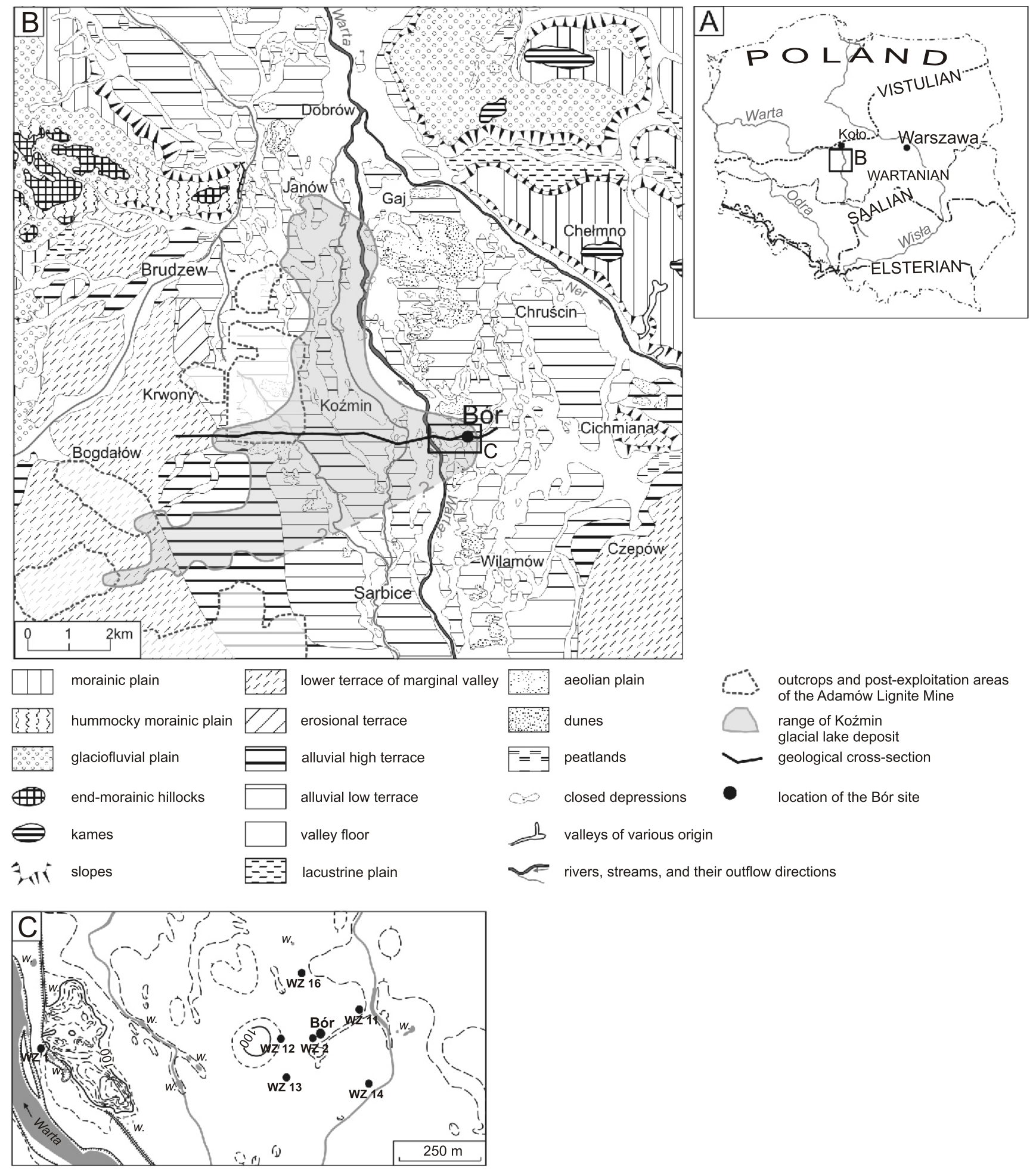

$\mathrm{D}$

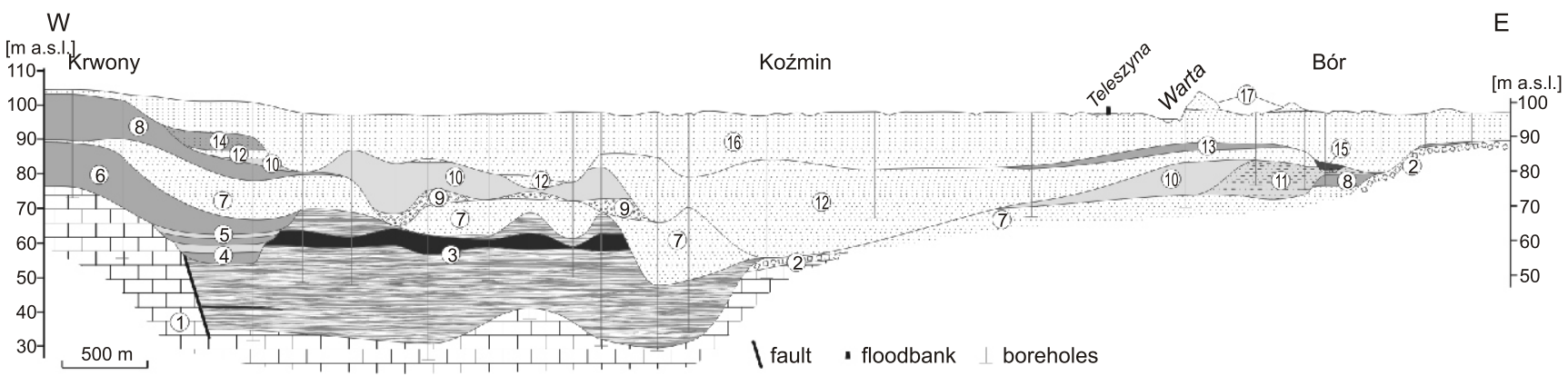




\section{GEOLOGICAL SETTING}

The Bór site is located in the middle section of the Warta River valley (Fig. 1A), in area where the valley joins with the Warsaw-Berlin ice-marginal streamway. Between Sarbice and Dobrów it widens and reaches a width of several $\mathrm{km}$. The study area lies within the Middle Polish Glaciations extent. During the Last Glacial Maximum the Bór site was situated in an extraglacial zone (Kozarski, 1981; Stankowska and Stankowski, 1988; Stankowski and Krzyszkowski 1991).

In the Mesozoic substratum of the investigated area the Adamów graben occurs. It belongs to the system of grabens of the Konin elevation, formed within the Szczecin-Łódź-Miechów Trough (Widera, 1998). Within the graben, thick Neogene deposits, including brown coal, and Quaternary series were accumulated.

The oldest Quaternary deposits are represented by tills and other glaciogenic deposits of South Polish Complex (based on stratigraphy postulated by Ber et al., 2007; Lindner and Marks, 2012), which filled deep erosional forms developed in the sub-Quaternary surface (Fig. 1D). The upper till of South Polish Complex (probably Sanian 2), are more widespread and deformed by glaciotectonic processes. Fluvial sands and sands with gravels representing beginning of the Middle Polish Complex lie above. Two horizons of the Middle Polish Complex tills were found (Czubla et al., 2010). Outside the Adamów graben the tills are thick, and dominate the Quaternary series, while in the graben their thickness decreases or they are completely eroded or/and separated by glaciolacustrine deposits of the Koźmin glacial lake and glaciofluvial sand and gravels (Fig. 1D). The glacigenic deposits of the Middle Polish Complex form uplands: morainic and glaciofluvial plains as well as the Warsaw-Berlin ice-marginal streamway terraces (Kłysz, 1981; Klatkowa, 1993; Nowacki, 1995; Trzmiel, 1996; Czubla, 2001; Forysiak, 2005).

Fluvial sands lying at a depth of 14-24 m were described as Eemian deposits by Czarnik (1972) and Trzmiel (1996). The organic sediments of Eemian age were recognized only at the Bór site. Nowadays, the site is located in the wide valley but in the Eemian, it was located in very distal part of the valley. The bottom of the Bór reservoir was close to the Adamów graben east edge (Fig. 1D).

The thick Weichselian alluvia, exceeding locally $20 \mathrm{~m}$ in thickness, cover older deposits (Fig. 1D). Morphologically, Weichselian deposits form two levels: the alluvial high terrace and lower terrace. The great part of the valley is occupied by the lower terrace (Fig. 1B). The lower terrace is cut by remains of the multichannel river system which developed in the Younger Dryas and also functioned in the Holocene. Some of the channels are still occupied by small streams (Petera, 2002; Turkowska et al., 2004; Forysiak, 2005).

The Holocene fluvial deposits usually occupy narrow fragments of the valley, along the numerous small streams and Warta River. They are represented by sands with silt and alluvial clay (Forysiak, 2005). The aeolian sands and dunes occur, the most frequently in the right side of the valley.

\section{MATERIAL AND METHOD}

The organic series were documented during drillings in the Bór site. There were undertaken drillings around the site (Fig. 1C) to establish their spread and geological context. At the Bór site the drilling reached a depth of $18.5 \mathrm{~m}$, and the vertical profile is as follows:

Depth [m]

$0.0-0.3$

$0.3-1.1$

$1.1-8.5$

$8.5-10.0$

$10.0-14.0$

$14.0-14.6$

$14.6-14.85$

$14.85-16.35$

$16.35-16.60$

$16.60-16.75$

$16.75-17.45$

17.45-17.95 fine and medium sand with silt

17.95-18.50 till

\section{ANALYSIS OF MINERAL DEPOSITS}

21 samples of mineral deposits (Fig. 2) were examined by grain-size analysis: sieve and aerometric method (Mycielska-Dowgiałło, 1995), and standard Folk and Ward coefficients were counted using GRADISTAT software. The quartz-grain abrasion analysis was performed for the fraction 0.8-0.63 mm, using modified Cailleux method (Klatkowa, 1991; Manikowska 1993). Moreover, the calcium carbonate content was determine for all mineral samples using the Scheibler method.

\section{ANALYSIS OF GYTTJA}

The gyttja from the Bór profile was analysed by means of pollen, Cladocera, granulometric and geochemistry analyses. The samples from detrital calcareous gyttja were collected in intervals of 10 and $5 \mathrm{~cm}$ from calcareous detrital gyttja, within the depth range of 14.9-16.6 m.

The pollen analyses were done for 20 samples. For the microscopic investigations the samples were prepared using Faegri and Iversen (1978) and Berglund (1979) methods. The results are presented as percentage pollen diagram drawn using POLPAL software.

The analysis of Cladocera was based on 21 samples of $1 \mathrm{~cm}^{3}$ volume and were processed according to the standard procedure (Frey, 1986). The taxonomy of cladoceran remains follows that presented by Frey (1962) and Szeroczyńska and

\section{Fig. 1. Location of the Bór site in Poland with geological sections}

A - location of the investigated area in relation to extents of the ice-sheets (after Marks, 2005a); B - geomorphological map (after Forysiak, 2005); C - location of the boreholes in Bór village; D - geological cross-section: Cretaceous: 1 - marl, 2 - weathered marl; Neogene: 3 - clay, silt, sand and lignite; Quaternary, Elsterian: 4 - the oldest till and glaciolacustrine silt, 5 - older till and glaciolacustrine silt, 6 - younger till; Saalian: 7 - fluvial sand and gravels; Wartanian: 8 - lower till, 9 - lower glaciofluvial sand and gravels, 10 - glaciolacustrine silt and fine sand, 11 - glaciolacustrine sand and sand with silt, 12 - upper glaciofluvial sand and gravels, 13 - upper till, 14 - glacial loamy sand; Eemian Interglacial: 15 - gyttja; Weichselian and Holocene: 16 - fluvial sand, sand and gravel, and sand with silt, 17 - aeolian sand 


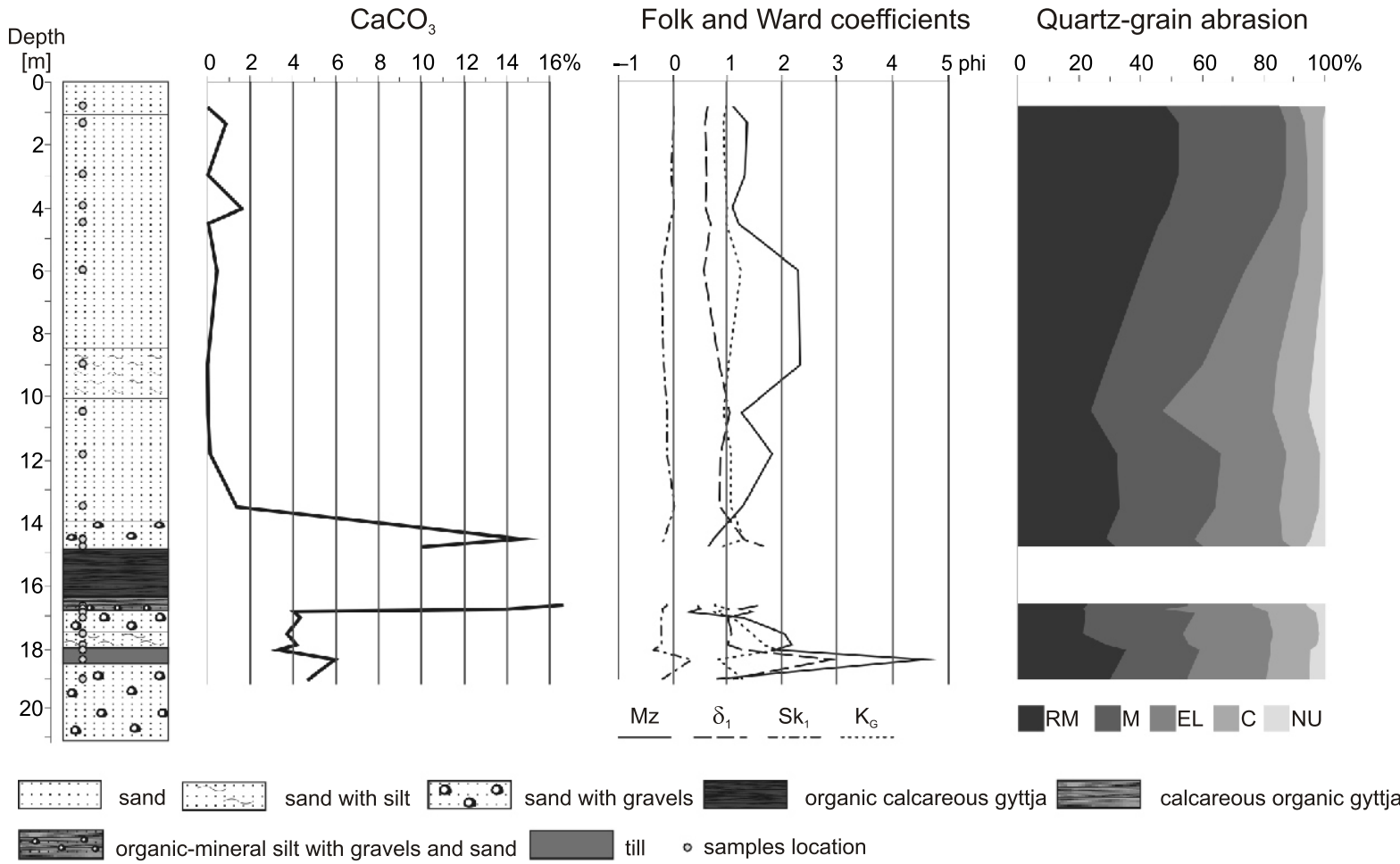

Fig. 2. Lithology and textural features of deposits in Bór site

$\mathrm{Mz}$ - mean grain-size, $\delta_{1}$ - standard deviation, $\mathrm{Sk}_{1}$ - skewness $\mathrm{K}_{\mathrm{G}}$ - curtosis, RM - round mat, $\mathrm{M}$ - intermediate, EL - shiny, $\mathrm{C}$ - crushed, NU - unabraded (fresh)

Sarmaja-Korjonen (2007). Ecological preferences of cladoceran taxa were determined on the basis of Whiteside (1970) and Szeroczyńska (1998).

Sediment granulometry and geochemistry was analysed in 21 samples. Individual samples were freeze-dried in lyophiliser and samples were mineralised in the process of combustion $\left(550^{\circ} \mathrm{C}\right)$ to calculate per cent contribution of organic and mineral parts of each sample. The ash produced by combustion was analysed for grain-size related and geochemical characteristics.

Grain-size analysis of the mineral part was carried out in a laser analyser which processes samples of 300-0.3 $\mu \mathrm{m}$ mean grain-size. Standard Folk and Ward coefficients were calculated using the GRADISTAT software. Percent contributions of individual fractions were calculated as well.

In order to perform geochemical assays, the ash samples were dissolved in Teflon bombs using a microwave mineraliser. Mineralisation was carried out in two microwave cycles: the first one in concentrated nitric acid with $2 \mathrm{ml} 10 \%$ chloric acid and the second one in hydrogen peroxide. The solution obtained was analysed for concentrations of $\mathrm{Na}, \mathrm{K}, \mathrm{Ca}, \mathrm{Mg}, \mathrm{Fe}, \mathrm{Mn}, \mathrm{Cu}, \mathrm{Zn}$, and $\mathrm{Pb}$ with atomic absorption spectrometry. All the analyses were conducted at the Geochemical Laboratory in University of Szczecin

Part of the geochemical analyses were conducted in Laboratory of the Earth Science Institute, University of Łódź. Twenty samples of sediment were analysed using the following methods: Scheibler volumetric method in order to determination of the carbonate content in the sediment, potentiometric method for measurement of $\mathrm{pH}$, conductivity and voltage.

\section{RESULTS}

\section{TEXTURAL FEATURES OF MINERAL DEPOSITS}

The till documented at the Bór site has typical textural features: high value of mean grain diameter, is poorly sorted, positive skewness coefficient and low value of kurtosis (Fig. 2). The quartz grain abrasion is representative for tills: RM (round mat) $\sim 35 \%$, M (intermediate) $\sim 25 \%$ and EL (shiny) $23 \%$ with high content of the broken grains. The $\mathrm{CaCO}_{3}$ content varies from about 4 to $6 \%$, which is typical as well. The top of the till has sand admixture, is better sorted and negatively skewed, probably due to fine fraction remove. Above, medium and fine-grained sands with silt occur. The deposits are medium or poorly sorted, with negative skewness and $\mathrm{CaCO}_{3}$ content of about $4 \%$. These sediments have been classified as glaciolacustrine deposits of the Koźmin glacial lake.

The next series consists of medium and poorly sorted coarse sand and gravels. The gyttja is underlain by organic-mineral silt with gravels and sand and covered by the Weichselian alluvia, represented by sand, sand with gravels, and fine sand with silt (Fig. 2). The content of $\mathrm{CaCO}_{3}$ in Weichselian deposits is low (about 1\%) except at the base where it reaches almost 15\%. At the base, the quartz grain abrasion is characterized by a relatively small amount of RM grains and a significant content of EL grains. At depths of about $8 \mathrm{~m}$ the proportions of RM and $\mathrm{M}$ grains increase towards the top, and reach, respectively about 50 and $35 \%$. Considerable content of wind-abraded grains is typical for Weichselian alluvia, as well for Warta River deposits (Petera, 2002; Forysiak, 2005). 


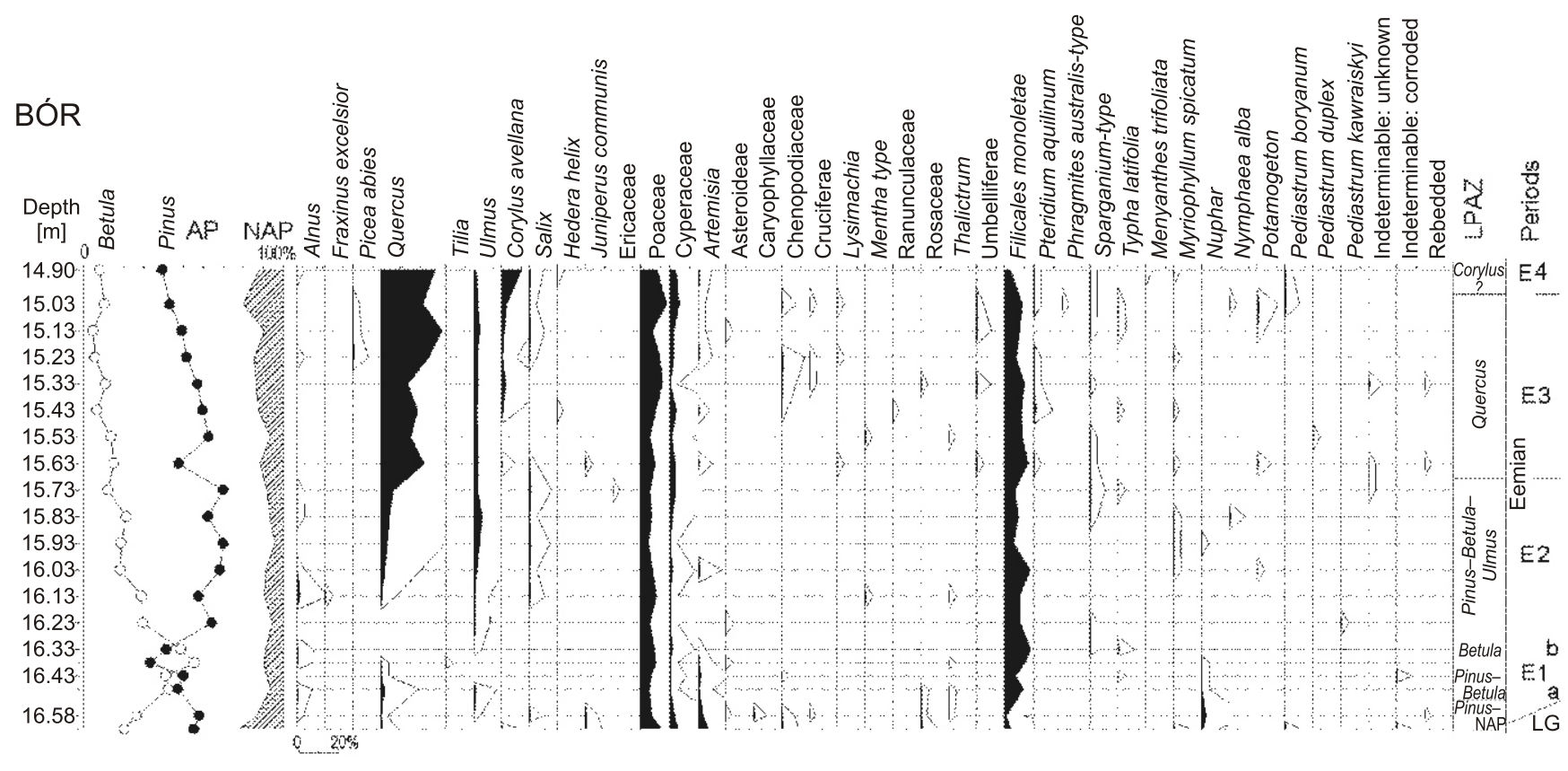

Fig. 3. Percentage pollen diagram

PROPERTIES OF ORGANIC DEPOSITS

POLLEN ANALYSIS

Changes of the percentage share of taxa in creation of vegetation associations in Bór borehole, allow for the distinction of six local pollen assemblage zones (LPAZ), according to Janczyk-Kopikowa (1987; Fig. 3).

Pinus-NAP LPAZ (16.48-16.63 m). Pinus (55.3-58.0\%) as the dominating taxon is accompanied by Betula (20.0-26.3\%) and in small amounts - Juniperus (0.8\%). Of the herbal plants (NAP: 23\%) the main constitutents are Cyperaceae and Poaceae and species of steppe-like associations (Artemisia, Chenopodiaceae). Predominance of non-forest associations in the vegetation shows that the sediments of this zone have been accumulated during the cold climate, probably in the period between the Late Glacial and the oldest Eemian.

Pinus-Betula LPAZ (16.38-16.48 m). A decrease of Pinus to $47.5 \%$ and an increase of Betula + Betula nana up to $42.4 \%$ is observed. The amount of NAP also decreases, especially Cyperaceae, Chenopodiaceae and Artemisia. It indicates the development of birch shrub associations and open birch-pine forests and shows the improvement of climate conditions proved also by presence of Typha latifolia pollen.

Betula LPAZ (16.23-16.38m). The dominance of Betula (to $55.6 \%$ ) over Pinus (33.2-41.3\%), shows the development of birch and birch-pine forests.

The zones Betula and Pinus-Betula, as well as probably the younger part of Pinus-NAP zone, we can correlate with the oldest regional pollen zone of Eemian - E1 (Mamakowa, 1988, 1989).

Pinus-Betula-Ulmus LPAZ (15.73-16.23 m). A high amount of Pinus (57.5-70.1\%) accompanied with a lower amount, in comparison to the previous zone, of Betula (11.9-29.5\%). Small amounts of pollen grains of Ulmus (max. $4.3 \%$ ) and Quercus (max. 6.5\%) are also present. The presence of new species proves the improvement of climate and edaphic conditions allowing the development of mixed forest with Ulmus and
Quercus. The general palynological picture of this zone allows for its correlation with the zone E2 in stratigraphic division of the Eemian (Mamakowa, 1988, 1989).

Quercus LPAZ (15.03-15.73 m). Quercus (15.2-30.9\%) is dominant and accompanied by Pinus (42.0-62.7\%), Betula $(4.7-14.9 \%)$ and Ulmus (1.9-3.1\%), as well as the continuous percentage curve (up to $2.2 \%$ ) of Corylus in the middle part. The pollen of Hedera proves the existence of a warm and humid climate (Iversen, 1958). The pollen spectra of this zone allow for its correlation it with the E3 zone in the Eemian vegetation succession (Mamakowa, 1988, 1989).

Corylus LPAZ (14.90-15.03 m). The characteristic feature is the significant amount of Corylus pollen grains (up to 10.5\%). Although this zone was distinguished on the basis of pollen spectrum of only one sample, we can associate it, with high probability, with the beginning of E4 zone in the Eemian succession (Mamakowa, 1988, 1989).

Summing up, the obtained palynological results are similar to previously described Eemian series known from other sites of central Poland (Noryśkiewicz, 1978; Stankowski and Tobolski, 1981; Jastrzębska-Mamełka, 1985; Tobolski, 1986, 1991a, b; Klatkowa and Balwierz, 1990; Klatkowa and Winter, 1990; Kotarbiński and Krupiński, 1995; Malkiewicz, 2002), which allows for a strong indication of the age of deposition of investigated sediments.

\section{CLADOCERA ANALYSIS}

In the Bór profile, 23 Cladocera species were recognized (Fig. 4), belonging to four families. The most numerous were the littoral species of the Chydoridae family. The number of pelagic forms (from the Bosminidae, Daphnidae and Sididae families) in places exceeds $30 \%$ of all Cladocera individuals.

On the basis of the Cladocera communities and the changes in frequency of the various species, five zones of Cladocera development were distinguished and connected with the Eeemian Interglacial period. 


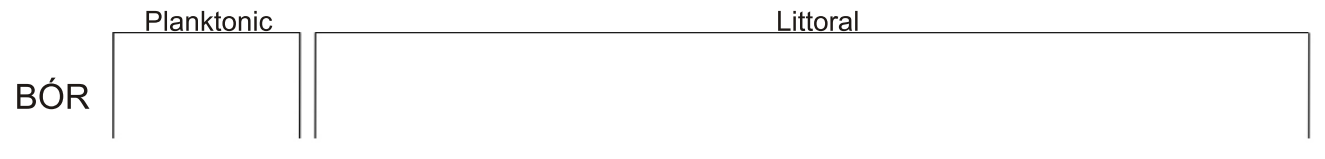

$$
P / L
$$

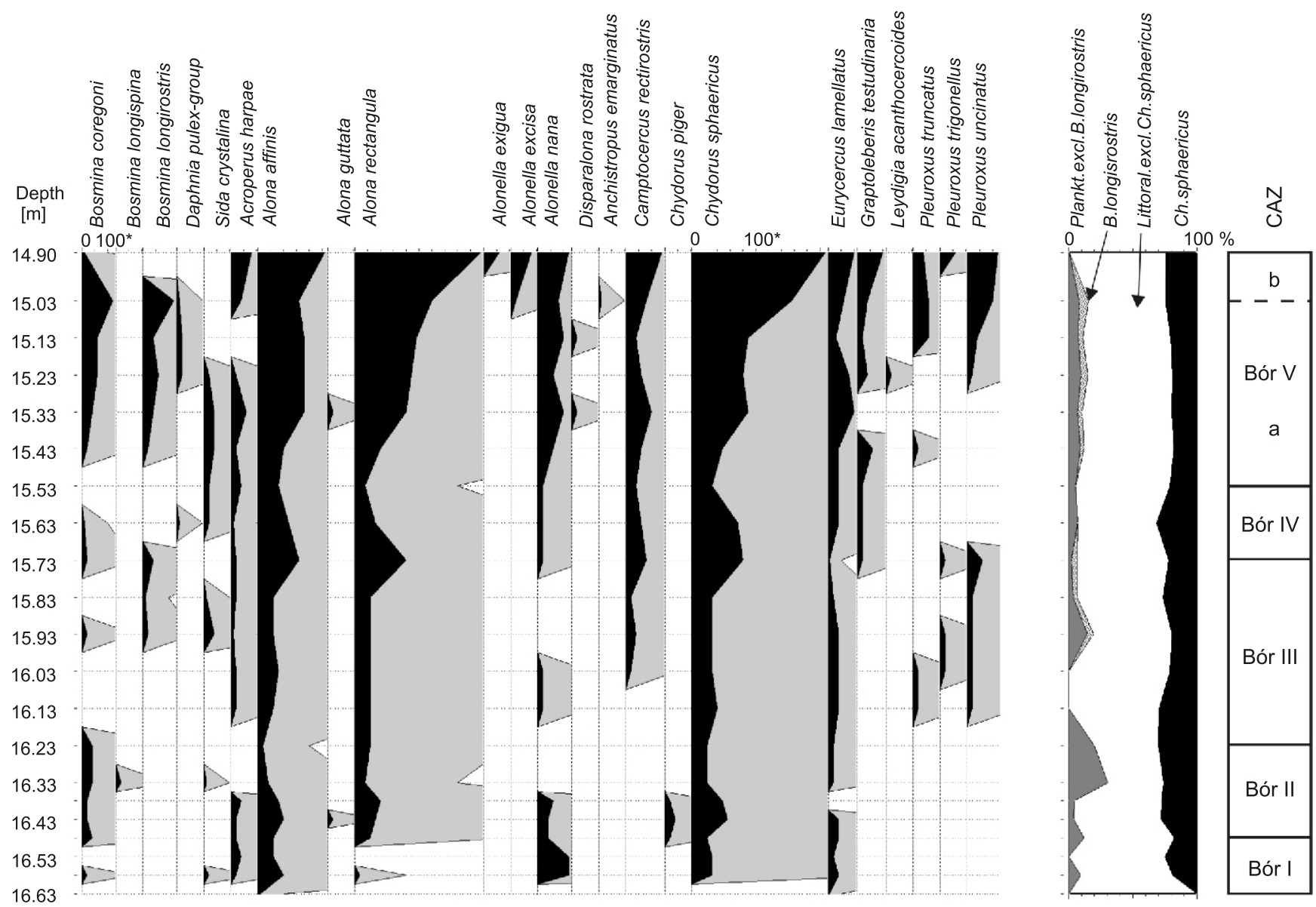

Fig. 4. Absolute number of Cladocera individuals, ratio of planktonic (P) to littoral (L) forms and proposed Cladocera zones (CAZ) in the sediments of Bór palaeolake

* - scale on diagram shows specimens in $1 \mathrm{~cm}^{3}$ of fresh sediments

Zone Bór I (16.48-16.63 m). At the beginning a low diversity of Cladocera is noted, comprising only two initial species: Alona affinis and Eurycercus lamellatus. Later the diversity of Cladocera species increases to 8 . The most numerous are Chydorus sphaericus, Alona affinis, Alonella nana and Acroperus harpae which tolerate cold water in the lake.

Zone Bór II (16.23-16.48 m). The planktonic form is noted up to $30 \%$ frequency of all Cladocera. The diversity of Cladocera species increases at the beginning to 9 species but later decreases to 5 species.

Zone Bór III (15.73-16.23 m). The diversity of Cladocera species increases to 12 species. These include species indicating warmer water: Camptocercus rectirostris, Pleuroxus trigonellus, $P$. truncatus and $P$. uncinatus, as well as macrophyte-associated species are present. Planktonic forms occur in middle part of this zone.

Zone Bór IV (15.53-15.73 m). The most numerous species are Chydorus sphaericus and Alona affinis. The diversity of Cladocera species decreases to 8 species at the end of the zone. Daphnia pulex and Graptoleberis testudinaria appear for the first time.
Zone Bór V (14.90-15.53 m). This zone is characterized by the maximum of zooplankton development. Fourteen species of Cladocera have been found, and two subzones have been distinguished. In subzone Bór Va (15.03-15.53 m) the diversity of Cladocera species systematically increases. Planktonic forms frequent reach $15 \%$ of all Cladocera. Among planktonic forms Bosmina longirostris dominates during periods of increased supply of nutrients. Among littoral forms Chydorus sphaericus and Alona rectangula dominate and Leydigia acanthocercoides and Disparalona rostrata appear for the first time. Species indicating warmer water e.g., Camptocercus rectirostris, Graptoleberis testudinaria and Pleuroxus spp., are also present accompanied by Acroperus harpae, Eurycercus lamellatus and Alona affinis, which are often associated with a high density of water plants. Subzone Bór Vb (14.90-15.03 m) is characterized by the highest frequency and diversity of Cladocera remains and species. Chydorus sphaericus and Alona rectangula dominate in this zone. The planktonic forms disappear and the presence of Graptoleberis testudinaria, Camptocercus rectirostris and Pleuroxus spp. suggests that the warm climatic conditions continued. 


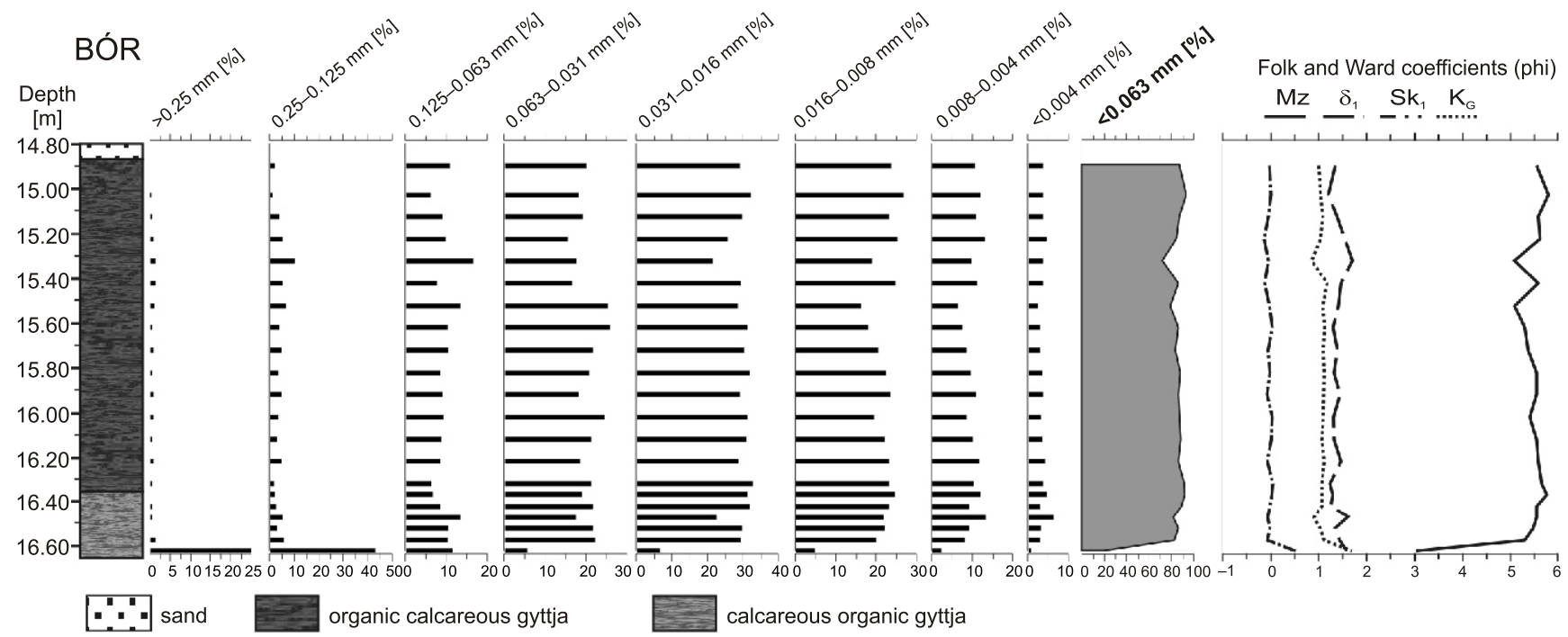

Fig. 5. Grain-size composition and Folk and Ward coefficients of the mineral matter in gyttja

Explanations as in Figure 2

\section{GEOCHEMISTRY}

The grain-size distribution varied only slightly along the studied profile. Excluding the lowest sample, the sediment consists of silts dominated by the coarse silt fraction $(0.031-0.016 \mathrm{~mm})$ which makes up, on the average, about $30 \%$ of the sample weight. The very coarse silt $(0.063-0.031 \mathrm{~mm})$ and moderately coarse silt $(0.016-0.008 \mathrm{~mm})$ account for 20 and $22 \%$, respectively (Fig. 5). The total content of silt-clay fraction $(<0.063 \mathrm{~mm})$ is $85 \%$ on average.

The grain-size variability in the profile was relatively low. It was noticed (on depth 15.5-16.5 m) that there is a tendency towards a gradual increase of the mean grain-size (Fig. 5). The tendency is primarily related to a reduction of moderate- and fine-grained silt fractions $(0.016-0.008$ and $0.008-0.004 \mathrm{~mm}$, respectively; Fig. 5). The standard deviation $\left(\delta_{1}\right)$, a measure of sediment sorting, varied from 1.1 to $1.7 \mathrm{phi}$, indicating poor sorting. Grain-size distribution skewness varied slightly only, from -0.1 to +0.1 , a range typical of symmetrical distributions (Racinowski et al., 2001).
In the organic deposits content of the $\mathrm{CaCO}_{3}$ is much higher than in mineral deposits and is $25.9 \%$ on average (Fig. 6). The highest value was obtained in the base part - in the calcareous detrital gyttja - almost $50 \%$. Determination of the reaction allows for the classification biogenic deposits as neutral and slightly alkaline (Okruszko, 1976). The lowest values were estimated in the base part while in the middle and top part of the organic deposits, reaction ranges from 7.2 to 7.5 . The conductivity of deposits is characterized by considerable variability. The value of that parameter exceeds $1200 \mu \mathrm{S}$ in the base, decreases in the middle part of the profile to $540 \mu \mathrm{S}$ and at the top again increases to $1280 \mu \mathrm{S}$.

Contents of sodium, potassium, magnesium and lead in the chemical composition of analysed sediment is, on average, much lower than those recorded in silty formations or sandstones (Table 1). Contents of copper and zinc is within the range typical to sandstones, whereas the content of calcium, iron, and manganese is distinctly higher, compared to contents known from silty deposits.

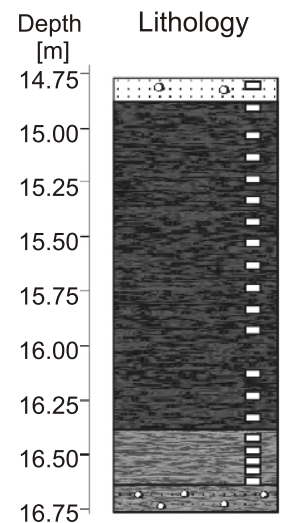

$16.75^{-}$
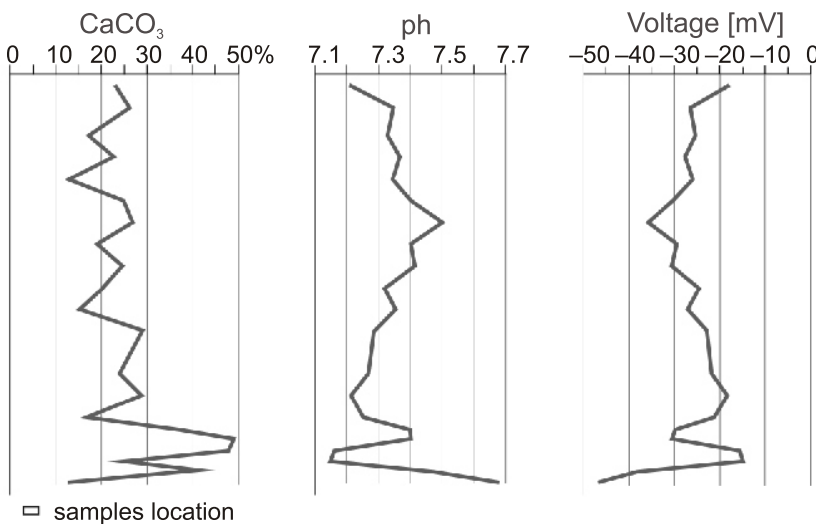

Conductivity [microS]

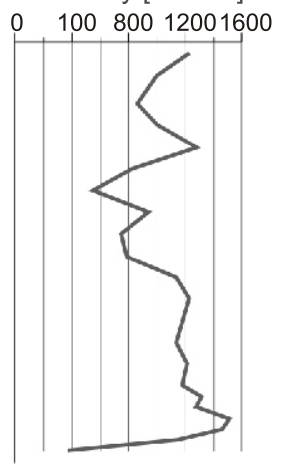

Fig. 6. Physicochemical properties of organic deposits from the Bór site 
Average concentration of mineral material (MO) and average contents of elements analysed in the profiles and geochemical intervals (cf. Fig. 5)

\begin{tabular}{|l|c|c|c|c|c|c|c|c|c|c|}
\hline $\begin{array}{l}\text { Geochemical } \\
\text { interval }\end{array}$ & $\begin{array}{c}\mathrm{MO} \\
{[\%]}\end{array}$ & $\begin{array}{c}\mathrm{Na} \\
{[\mathrm{mg} / \mathrm{g}]}\end{array}$ & $\begin{array}{c}\mathrm{K} \\
{[\mathrm{mg} / \mathrm{g}]}\end{array}$ & $\begin{array}{c}\mathrm{Ca} \\
{[\mathrm{mg} / \mathrm{g}]}\end{array}$ & $\begin{array}{c}\mathrm{Mg} \\
{[\mathrm{mg} / \mathrm{g}]}\end{array}$ & $\begin{array}{c}\mathrm{Fe} \\
{[\mathrm{mg} / \mathrm{g}]}\end{array}$ & $\begin{array}{c}\mathrm{Mn} \\
{[\mathrm{mg} / \mathrm{g}]}\end{array}$ & $\begin{array}{c}\mathrm{Cu} \\
{[\mu \mathrm{g} / \mathrm{g}]}\end{array}$ & $\begin{array}{c}\mathrm{Zn} \\
{[\mu \mathrm{g} / \mathrm{g}]}\end{array}$ & $\begin{array}{c}\mathrm{Pb} \\
{[\mu \mathrm{g} / \mathrm{g}}\end{array}$ \\
\hline Bór; average & 17.1 & 0.16 & 1.37 & 108.9 & 3.20 & 48.92 & 1.34 & 7.48 & 35.53 & 1.20 \\
\hline Silty deposits* $^{*}$ & - & $7-15$ & 22 & 22 & 15 & $33-47$ & $0.4-0.8$ & $40-60$ & $80-120$ & $20-40$ \\
\hline Sandstones * $^{*}$ & - & $10-15$ & 12 & 27 & $7-10$ & $9-30$ & $0.1-0.5$ & $5-30$ & $15-30$ & $5-10$ \\
\hline Bór III & 15.7 & 0.15 & 1.35 & 95.1 & 3.15 & 52.24 & 1.36 & 6.92 & 32.88 & 0.62 \\
\hline Bór II & 22.9 & 0.17 & 1.60 & 96.4 & 3.53 & 47.78 & 1.75 & 8.68 & 45.82 & 1.93 \\
\hline Bór I & 7.1 & 0.13 & 0.91 & 150.5 & 2.58 & 47.21 & 0.47 & 5.76 & 18.14 & 0.46 \\
\hline
\end{tabular}

* - contents most frequently found in silty deposits and sandstones (according to Kabata-Pendias and Pendias, 1993)

Table 2

Bór profile: coefficients of correlation between metal contents and per cent contribution of silt-clay fraction $(<0.063 \mathrm{~mm})$ and organic matter concentration (bold characters denote highly significant correlations, as shown by Student's $t$ test)

\begin{tabular}{|c|c|c|c|c|c|c|c|c|c|c|c|}
\hline$R$ & 0.063 & $\mathrm{MO}$ & $\mathrm{Na}$ & $\mathrm{K}$ & $\mathrm{Ca}$ & $\mathrm{Mg}$ & $\mathrm{Fe}$ & $\mathrm{Mn}$ & $\mathrm{Cu}$ & $\mathrm{Zn}$ & $\mathrm{Pb}$ \\
\hline 0.063 & 1 & & & & & & & & & & \\
\hline MO & 0.51 & 1 & & & & & & & & & \\
\hline $\mathrm{Na}$ & 0.67 & 0.62 & 1 & & & & & & & & \\
\hline $\mathrm{K}$ & 0.52 & 0.60 & 0.88 & 1 & & & & & & & \\
\hline $\mathrm{Ca}$ & 0.43 & -0.14 & 0.02 & -0.15 & 1 & & & & & & \\
\hline $\mathrm{Mg}$ & 0.57 & 0.64 & 0.84 & 0.88 & 0.12 & 1 & & & & & \\
\hline $\mathrm{Fe}$ & 0.63 & 0.24 & 0.53 & 0.42 & 0.46 & 0.53 & 1 & & & & \\
\hline $\mathrm{Mn}$ & 0.46 & 0.93 & 0.52 & 0.49 & -0.11 & 0.52 & 0.23 & 1 & & & \\
\hline $\mathrm{Cu}$ & 0.42 & 0.81 & 0.56 & 0.60 & -0.27 & 0.52 & 0.12 & 0.66 & 1 & & \\
\hline $\mathrm{Zn}$ & 0.54 & 0.88 & 0.70 & 0.72 & -0.03 & 0.79 & 0.24 & 0.78 & 0.73 & 1 & \\
\hline $\mathrm{Pb}$ & 0.39 & 0.48 & 0.74 & 0.82 & -0.08 & 0.76 & 0.15 & 0.28 & 0.51 & 0.74 & 1 \\
\hline
\end{tabular}

The analysed sediments show a statistically significant (at the level of $0.1 \%$ ) positive correlation between the concentration of organic matter and the contents of manganese, zinc, and copper as well as weak correlation in case of magnesium, sodium, and potassium (Table 2). Moreover, significant connections are observed in contents of $\mathrm{Zn}$ and $\mathrm{Mg}, \mathrm{Cu}$ and $\mathrm{Mn}$, and some lithophilous metals: $\mathrm{Na}$ and $\mathrm{K}, \mathrm{Na}$ and $\mathrm{Mg}$, and $\mathrm{K}$ and $\mathrm{Mg}$ ( $\mathrm{Ta}-$ ble 2). Calcium and iron do not show stronger correlations with other assayed elements. The percentage content of silt-clay fraction $(<0.063 \mathrm{~mm})$, correlates the strongest with content of sodium and iron (Table 2), although the significance of those correlations is at the level of $1 \%$.

Analysis of geochemical diagrams (Figs. 7 and 8) allow for the identification of three geochemical intervals, which are markedly different in their chemical composition.

Interval Bór I (16.43-16.63 m) shows the highest content of mineral material $(>92 \%)$, and calcium $(150.5 \mathrm{mg} / \mathrm{g}$ ) but the lowest values of the remaining elements, particularly potassium, manganese and zinc (Table 1). The highest $\mathrm{Fe} / \mathrm{Mn}$ ratio $(80-180)$ as well as somewhat elevated $\mathrm{Cu} / \mathrm{Zn}$ and $\mathrm{Ca} / \mathrm{Mg}$ are observed (Fig. 8).

Interval Bór II (15.5-16.43m) contain on average $22.9 \%$ organic matter (up to about $30 \%$ ). This level is characterized by relatively the highest concentrations of all metals except iron, while the high contents of $\mathrm{Ca}$ and $\mathrm{Zn}$ in the base of interval distinctly decreases to the top. In the case of the other elements there are only some slight variation of the contents, which are associated only to a small extent with subtle changes in lithology, what is visible, inter alia, in correlations of organic matter content and percentage of clay-silty fraction with each metal.

Throughout the interval the $\mathrm{Fe} / \mathrm{Mn}$ and $\mathrm{Cu} / \mathrm{Zn}$ ratios are uniform and low. On the other hand, the $\mathrm{Fe} / \mathrm{Ca}$ ratio was clearly higher than in the Interval Bór I, indicating an increasing trophic status of the basin. Minor variations of $\mathrm{Ca} / \mathrm{Mg}$ ratio are observed, what probably reflect subtle changes in the supply of mineral deposits.

Interval Bór III (14.90-15.50 m) was identified on the base of changing in the trend of the calcium and zinc contents in the profile (Fig. 7). Contents of individual metals, except iron, are lower than those in Interval Bór II. In addition, the interval shows initially a growing and then a decreasing trend in the content of almost all elements, which reflects changes in grain-size of the mineral fraction (Fig. 5) which attain, on average, ca. $85 \%$. In the top part of the interval the $\mathrm{Fe} / \mathrm{Mn}$ ratio increases. 


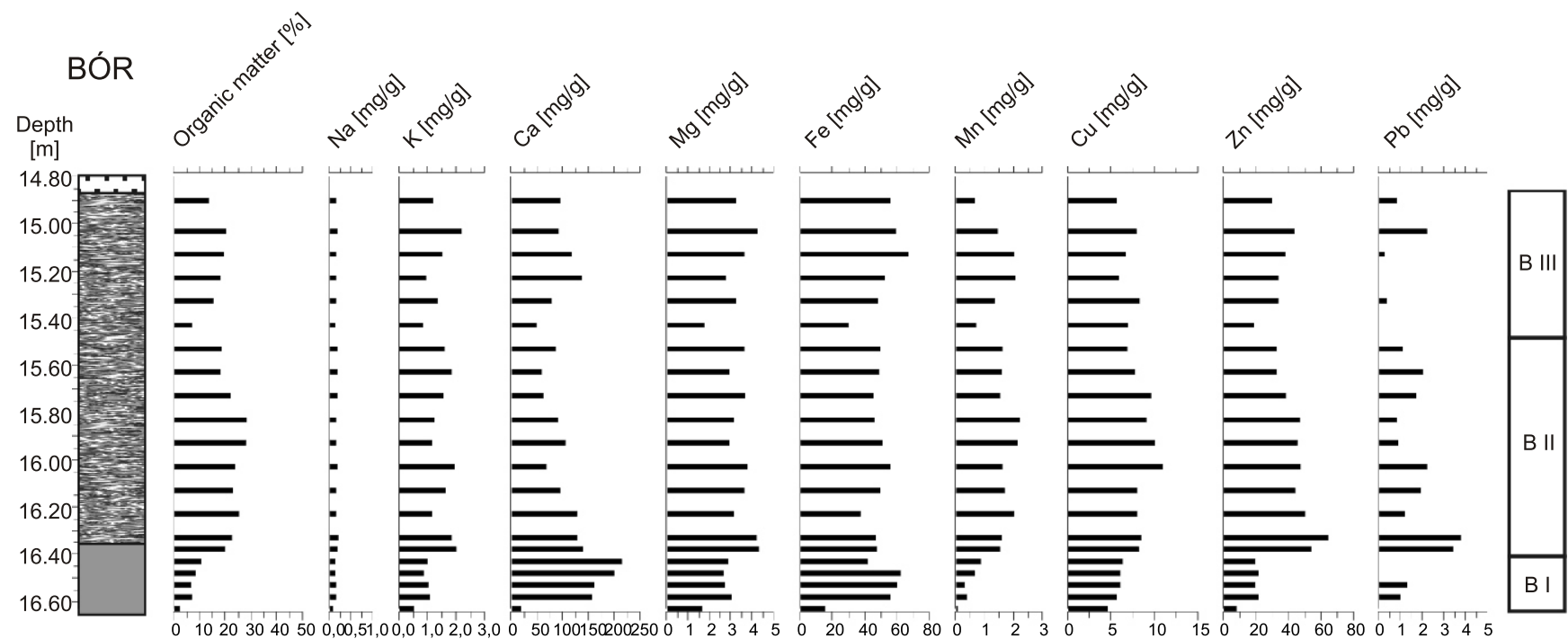

\section{$\because$ sand organic calcareous gyttja $\quad \square$ calcareous organic gyttja}

Fig. 7. Geochemical diagram

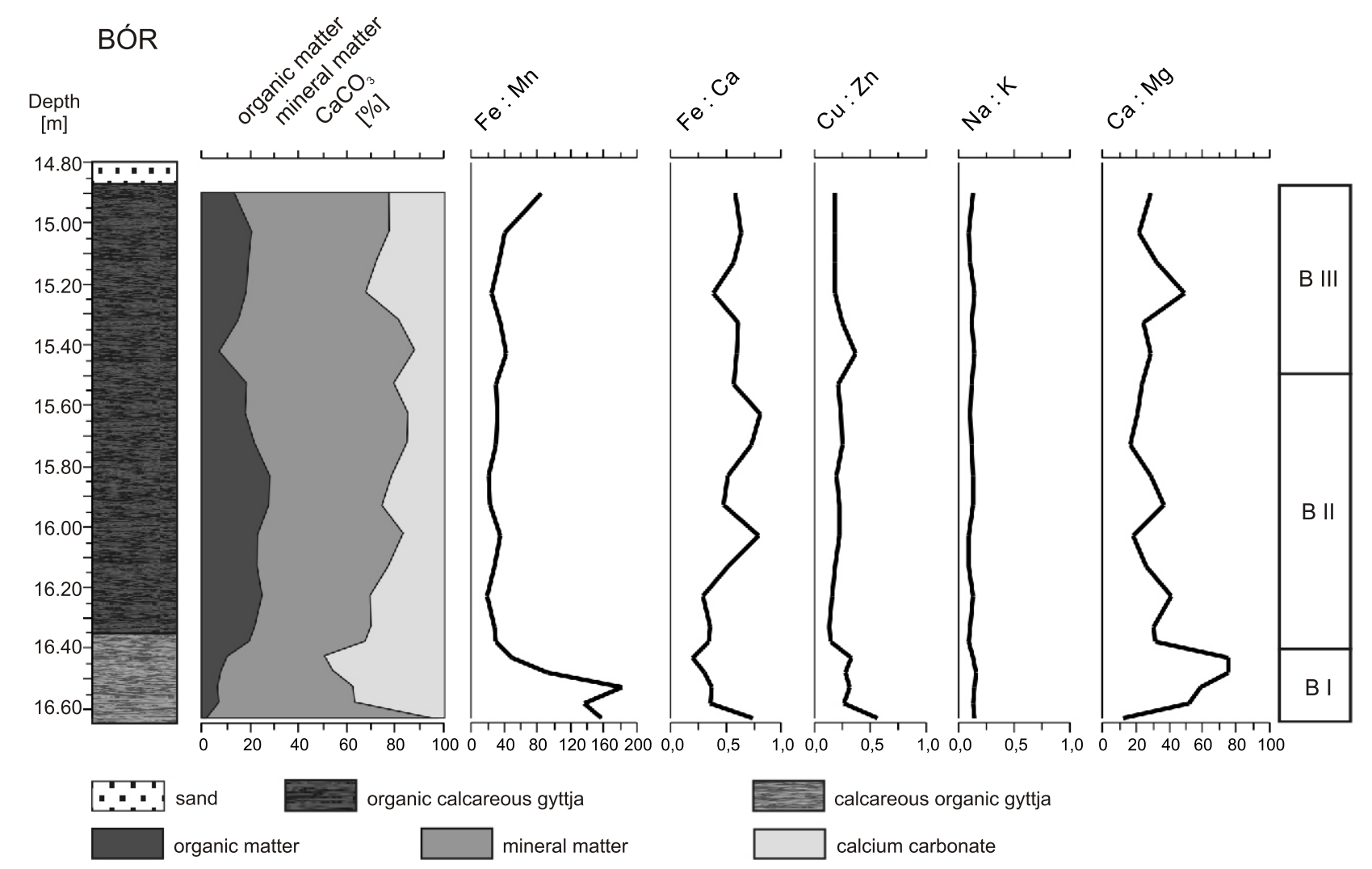

Fig. 8. Vertical differentiation of selected geochemical parameters 


\section{PHASES OF THE BÓR PALAEOLAKE DEVELOPMENT}

The obtained results allow to distinguish four phases of the lake development in the Bór site (Fig. 9):

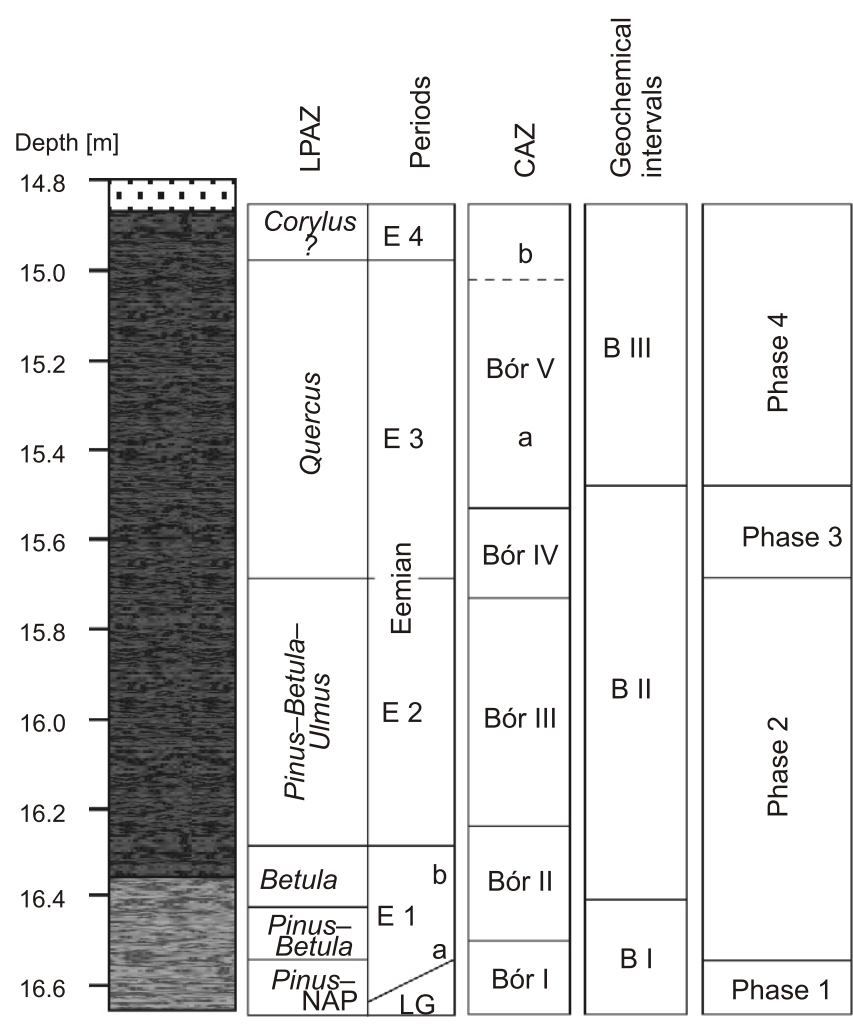

Fig. 9. Phases of the Bór palaeolake development

Phase $1(16.53-16.63 \mathrm{~m})$

The lowest part of the investigated sediments was deposited in the final part of the Wartanian, in a cold climate when tundra associations were present and intensive calcium carbonate supply to the sedimentary basin took place. That period was also characterized by a high, although gradually decreasing, intensity of mechanical denudation processes indicated by more than $90 \%$ contribution of the mineral fraction, at first sandy and then silt-clay (Fig. 5) and the high Fe/Mn ratio with the simultaneous high Fe contents (Mackereth, 1966). It may be concluded that sedimentation at Phase 1 proceeded during a cool climate when the plant cover was sparse, which is in agreement with the pollen analysis results. The conditions were most probably analogous to those prevalent in the Late Glacial in the European Lowland, when intense mechanical denudation was accompanied by carbonate deposition in sedimentary basins, particularly as a result of hydrocarbonate iron supply with groundwater (Nowaczyk and Tobolski, 1980; Kowalkowski, 1988; Borówka, 1992; Borówka and Tomkowiak, 2010; Forysiak et al., 2010). At the beginning Cladocera species tolerating cool, oligotrophic water existed in the lake. The slightly higher amount of Cladocera and presence of planktonic forms might be a consequence of favorable conditions like an increase in the amount of water in the reservoir and/or better thermal conditions. The sediments of the upper part of this phase, probably developed in the very beginning of Eemian Interglacial.

Phase 2 (15.68-16.53 m)

The characteristic feature of the Phase 2 is the highest content of the organic material $(>20 \%)$ and significant amount of $\mathrm{CaCO}_{3}(15-30 \%)$. This phase include three LPAZ: Pinus-Betula, Betula, and Pinus-Betula-Ulmus, which are correlated with the oldest regional pollen zones of Eemian - E1 and E2. The beginning of the Eemian Interglacial was expressed by a greater diversity of Cladocera (Fig. 4) and the initially high frequency of planktonic forms (Cladocera zone Bór II). It is possible that this situation was respond to increase of water table. The diversity of Cladocera species increased at the beginning but later decreased to rise again (Cladocera zone Bór III). Species indicating warmer water, Camptocercus rectirostris, Pleuroxus trigonellus, $P$. truncatus and $P$. uncinatus are present. Also species associated with a high density of water plants, occur there. Lack of planktonic forms which is observed in middle part of this zone, probably indicates a short-term shallowing, but can also be a response to geochemical changes in water (Fig. 7) or reflect subtle changes in the supply of mineral deposits (Fig. 5).

Higher organic matter concentration, accompanied by a simultaneous increase of the $\mathrm{Fe} / \mathrm{Ca}$ ratio, which indicate a raising of the trophic level, most likely associated with warming of the climate. In the base part of the Phase 2 (lower part of the geochemical Interval Bór II), the highest $\mathrm{Zn}$ and $\mathrm{Pb}$ contents are observed, likely as a result of bioaccumulation of those elements. The increase in $\mathrm{Zn}$ content could have been associated with the appearance of the light-requiring birch characterized as having a strong ability to bioconcentrate zinc (Fortescue, 1980; Reimann et al., 2007). The relatively low Fe/Mn ratios evidenced persistence of oxidative conditions in the water body (Mackereth, 1966; Borówka, 2007).

Phase 3 (15.50-15.68 m)

In the Phase 3 the percentage of the mineral material increases and values of the Mz coefficient decreases, what indicates that the basin became a recipient of a fairly high amount of mineral material, including fine sands. It may thus be contended that the water body was either a flow-through. The Phase 3 is connected with the beginning of the Quercus LPAZ with characteristic rapid increase amount of Quercus pollen and increased percentage of the NAP, including plants of wet communities. The diversity of Cladocera species decreases at the end of phase, the most numerous were Chydorus sphaericus and Alona affinis. Daphnia pulex and Graptoleberis testudinaria appears for the first time. The occurrence of Daphnia pulex, which is a species typical of the open-water zone, suggests a slight raise of the water level in the reservoir, perhaps due to the inflow of flood waters into the basin.

The vegetation cover was dense in this part of the Eemian Interglacial, which excludes the intensification of the denudation or aeolian processes. The increasing of humidity and water level in the lake can by accounted for flood activity.

The gradual reduction of calcium carbonate content (Fig. 8) can indicate a decreasing rate of leaching of that compound from the former drainage area, which could have been associated with: exhaustion of $\mathrm{CaCO}_{3}$ resources in the drainage area, more compact vegetation cover which can inhibit leaching $\mathrm{CaCO}_{3}$ from soil by binding the compound via biochemical processes, or a change in the precipitation-evapotranspiration rela- 
tionships in favour of evapotranspiration, which is associated with reduced infiltration of precipitation and in consequence leaching of carbonates, characterized by high solubility in water. An intake of water during floods can be take into consideration as well.

Phase $4(14.90-15.50 \mathrm{~m})$

The Phase 4 is correlated with the upper part of the level Quercus LPAZ (E 3) and Corylus LPAZ (E 4) which determine the climatic Eemian Interglacial optimum (Mamakowa, 1988, 1989). The increase of the sum of the herbs and plants characteristic for wet communities probably reflect local conditions in the river valley bottom, whereas in case of high groundwater level a larger role could have been played by open, treeless communities.

In the Phase 4 the number of Cladocera species rapidly increased (Cladocera zone Bór $\mathrm{Va}$ ). The presence of "thermophilic species" shows the continued warm climatic conditions. An increase in the number of phytophilous cladocerans indicates the rich macrovegetation in the lake. Presence of species which have bigger requirements, suggests a higher trophic level of the lake. Occurrence of planktonic species, which living in open-water zone suggests sufficient of water level, but finally a reduction of planktonic forms took place (Cladocera zone Bór $\mathrm{Vb})$.

The high trophic level is indicated by results of analysis of changes in the Fe/Ca ratio in Interval Bór III (Fig. 8). At the same time, the supply of mineral matter, including $\mathrm{CaCO}_{3}$, increased. There is also a tendency towards an increase in the Fe/Mn ratio accompanying the high iron content (Figs. 7 and 8), which also evidences the domination of allochthonous mineral matter supply (Mackereth, 1966; Boyle, 2001). It may be thus inferred that the study site located in a river valley, was experiencing an increased frequency of floods. The basin itself accumulated not only the flood-borne sediment, but also deposited plant remains (mainly leaves), which would explain the persistence of rather high $\mathrm{CaCO}_{3}$ concentrations.

\section{DISCUSSION AND PALAEOGEOGRAPHICAL CONCLUSIONS}

The Bór palaeolake was a small and shallow reservoir located in the distal part of the former valley, rather far from the active river channel and close to the valley edge, where the Mesozoic substratum lays relatively high. The lake appeared as a result of abandonment of one of the channels or subchannels of the braided river which developed in the Warta River valley during the Wartanian termination. The beginning of the lake infilling took place during that time and lasted, at least to the Eemian Interglacial optimum. The top part of the organic deposits were most probably - eroded due to intensive fluvial processes in Weichselian.

The palynological record starts from the end of the Wartanian. During that period the cladoceran succession comprises a very rich frequency which might be mirrored by a favourable conditions for zooplankton. The sediments of the Borr palaeolake were accumulated in a humid environment, most probably on the shore, which is supported by the presence of pollen grains originating from: rushes (Sparganium, Typhalatifolia), water plants (Nuphar, Potamogeton, Myriophyllum) and large amounts of fern spores (Filicales) in the sediments. The Cladocera species indicate the oligotrophic status of the lake initially and then an increase of the trophic status in Eemian optimum. At the beginning of the Eemian optimum the water level increased, which is indicated by the increasing amount of pollen grains of the water plants and planktonic Cladocera forms. Next, the reservoir became shallower, but probably the ground water level was high, what effected in places on development of the treeless, wet communities. Generally, conditions in Bór reservoir are similar to other Polish Eemian palaeolakes (e.g,. Tobolski, 1991a; Malkiewicz, 2002; Mirosław-Grabowska et al., 2009; Pawłowski, 2011).

The impossibility of a reconstruction of the former topography made an estimation of the intensity of denudation processes difficult. The obtained results point to a lake mostly fed by calcium carbonate-rich groundwater, which is understandable in the case of nearby Mesozoic substratum. However, the sediments also contain a high proportion of carbonate-free mineral fraction, therefore it has to be assumed that it was supplied to the basin via surface transport. It is most probable that the accumulation proceeded in a small lake developed from an abandoned channel located close to a valley margin, periodically fed by surface waters and at the same time experiencing conditions amenable to groundwater transport. Physicochemical properties of deposits from Bór palaeolake are comparable to results obtained for contemporary peatland in the Bartochów site, located in the Warta River valley at the base of the Warta Hills, possibly, in an analogous situation.

The applied methods like pollen, Cladocera, geochemistry, and lithological analyses, as well as palaeogeomorphological analyses allowed for the reconstruction of an image of the functioning of the reservoir during time from Wartanian termination to Eemian Interglacial optimum. A key point of the studies was to establish the spatial relation between the Mesozoic substratum and the palaeolake location. The influence of the Mesozoic substratum manifested in the geochemical properties of the deposits and results led to the conclusion about the methods of feeding the lake. The results of investigations in the Bór site shows how important are detailed multi-proxy analyses of the organic deposits in order to establish an as wide as possible geological context which confer the possibility of reconstruct the various elements of the palaeoenvironment. It is worth investigating the river valleys, because such an investigation can provide valuable and various information.

It is worth paying attention to the estimated level of the valley beds of the sections of Warta and Vistula rivers within the Warsaw-Berlin ice-marginal streamway in Eemian Interglacial. On the west side there are two sites with Eemian Interglacial biogenic sediments: Krzyżówki (located about $2 \mathrm{~km}$ to the north-west from Koło, on the right bank of the Warcica River right tributary of the Warta River) and Bór (located in the Warta River valley about $3 \mathrm{~km}$ south from the contemporary mouth of the Ner River) which is presented here. The base of the biogenic deposits at altitudes of $80.8 \mathrm{~m}$ a.s.l. in the Bór and about $71 \mathrm{~m}$ a.s.I. in the Krzyżówki confirm a similarity to the present course of the Warta River. On the east side the Vistula River bed in the Bzura River mouth area is located at about $54 \mathrm{~m}$ a.s.l. (Marks and Pochocka, 1999) and the bed of Eemian alluvia in Łęczyca vicinity lay at altitudes about $75 \mathrm{~m}$ a.s.I. (Jewtuchowicz, 1967). The implications of these facts are connected with the direction of the flow of the rivers drained the Łódź Plateau in the sections within Warsaw-Berlin ice-marginal streamway - to the east or to the west as Jewtuchowicz (1967) claimed. Taking into account the altitude of the Lower Bzura Valley in the Eemian Interglacial, the valleys of the rivers, which flowed through the edge zone of the Łódź Plateau should be incised deeper. Assuming that the Lower Ner Valley bed has dropped gradually similarly to those in the present day, the base level of erosion of the valleys men- 
tioned above, should have lie on altitude $80-90 \mathrm{~m}$ a.s.I. and raising to the east. It corresponds well with the position of Eemian Interglacial and Early Weichselian biogenic sediments, deposited in the valley beds or wide basins in Piaski Stare (Jewtuchowicz, 1970), Walewice (Dylik, 1967), in Moszczenica Valley near Gieczno (Kamiński, 1993) and in Bobrówka Valley (Klajnert and Piechocki, 1972). These facts point to different from the present, direction of outflow of the river within the Warsaw-Berlin ice-marginal streamway in the Eemian Interglacial.

The reconstructed image of the Warta River valley during the Eemian Interglacial, compared with its contemporary image shows, how big is the transformation of fluvial relief in the past 130,000 years. Topographic differences in the valley between the edge and the bottom of the valley declined, in some parts, more than twofold (e.g., in Dobrów). The Warta River valley was a transitional valley, running through the Eemian lakeland (Klatkowa, 1990). The source area was certainly beyond the reach of the Middle Polish Glaciations, to the Koło vicinity running in a similar way as it does currently. Its downstream course is not entirely explained, however, there are suggestions that the river flowed directly north, to the Baltic Basin (Mojski, 2005).

It is also worth paying attention to the lack of an upper part of the interglacial profile (from the upper part of the Eemian Interglacial optimum) at the Bór site and in Peene Valley (Meng et al., 2009), and a hiatus in the top of the Eemian optimum in Krzyżówki site (Noryśkiewicz, 1999). One may wonder if there is a general tendency of some climate change after optimum, resulting in erosion, lowering of the groundwater level and the end of the deposition of organic sediments. However, current state of research lead to interpretation of absence of the upper parts of profiles, as an effect of Weichselian erosion.

Acknowledgements. The study was supported by a grant from the Polish Ministry of Science and Higher Education, No N 306284033 "Origin, age and depositional conditions of Koźmin glacial lake sediments (Koło Basin, Central Poland)". The authors are grateful to the reviewers: H. Winter and J. Satkūnas and editors: T. Peryt and W. Granoszewski for revision and valuable comments.

\section{REFERENCES}

Ber A., Lindner L., Marks L. (2007) Propozycja podziału stratygraficznego czwartorzędu Polski. Przegląd Geologiczny, 55: $115-118$

Berglund B.E. (1979) Pollen analysis. In: Palaeohydrological changes in the temperate zone in the last 15000 years (ed. B.E. Berglund). Subproject B, 2: 133-167.

Borówka R.K. (1992) The pattern and magnitude of denudation in intraplateau sedimentary basins during the Vistulian and Holocene (in Polish with English summary). Adam Mickiewicz University Press, Seria Geografia, 54: 1-177.

Borówka R.K. (2007) Geochemiczne badania osadów jeziornych strefy umiarkowanej. Studia Limnologica et Telmatologica, 1: 33-42.

Borówka R.K., Tomkowiak J. (2010) Skład chemiczny osadów z profilu torfowiska Żabieniec. In: Torfowisko Żabieniec: warunki naturalne, rozwój i zapis zmian paleoekologicznych w jego osadach (ed. J. Twardy, S. Żurek and J. Forysiak): 163-172. Bogucki Wydawnictwo Naukowe, Poznań,

Boyle J.F. (2001) Inorganic geochemical methods in palaeolimnology. In: Tracking Environmental Change Using Lake Sediments, 2. Physical and geochemical methods (ed. W.M. Last, J.P. Smol): 83-140. Kluwer Academic Publishers, Dordrecht.

Bruj M., Roman M. (2007) The Eemian lakeland extent in Poland versus stratigraphical position of the Middle Polish Glaciations (in Polish with English summary). Biuletyn Państwowego Instytutu Geologicznego, 425: 27-34.

Czarnik J. (1972) Paleogeography of the environs of Turek in the Upper Tertiary and Pleistocene (in Polish with English summary). Studia Geologica Polonica, 40.

Czubla P. (2001) Fennoscandian erratics in Quaternary Deposits of Middle Poland and their value for stratigraphic purposes (in Polish with English summary). Acta Geographica Lodziensia, $\mathbf{8 0}$.

Czubla P., Forysiak J., Petera-Zganiacz J. (2010) Lithologic and petrographic features of tills in the Koźmin region and their value for stratigraphical interpretation of the deposits of the Koźmin glacial lake, central Poland. Geologija, 52 (1-4): 1-8.

Dylik J. (1967) Site VIII/28 Walewice. Guide of Excursion of the Symposium of the Commission on the Evolution of Slopes and of the Commission on Periglacial Geomorphology of the International Geographical Union, Poland: 84-93.
Faegri K., Iversen J. (1978) Podręcznik analizy pyłkowej Wydawnictwo Geologiczne.

Fortescue J.A.C. (1980) Environmental geochemistry. A holistic approach. New York, Springer-Verlag.

Forysiak J. (2005) The development of the Warta River valley between Burzenin and Dobrów in the Late Quaternary period (in Polish with English summary). Acta Geographica Lodziensia, $9 \mathbf{0 .}$

Forysiak J., Borówka R.K., Pawłowski D., Płóciennik M., Twardy J., Żelazna-Wieczorek J., Koss M., Żurek S. (2010) Rozwój zbiornika Żabieniec w późnym glacjale i jego znaczenie dla paleoekologii i paleogeografii. In: Torfowisko Żabieniec. Warunki naturalne, rozwój i zapis zmian paleoekologicznych w jego osadach (ed. J. Twardy, S. Żurek, J. Forysiak): 191-202. Bogucki Wydawnictwo Naukowe, Poznań.

Frey D.G. (1962) Cladocera from the Eemian Interglacial of Denmark. Journal of Paleontology, 36: 1133-1154.

Frey D.G. (1986) Cladocera analysis. In: Handbook of Holocene Paleoecology and Paleohydrology (ed. B.E. Berglund): 667-692. John Willey and Sons.

Iversen J. (1958) The bearing of glacial and interglacial epochs on the formation and extinction of plant taxa. Uppsala Universiteit Arssk, 6: 210-215.

Janczyk-Kopikowa Z. (1987) Remarks on palynostratigraphy of the Quaternary (in Polish with English summary). Kwartalnik Geologiczny, 31 (1): 155-163.

Jastrzębska-Mamełka M. (1985) The Eemian Interglacial and Early Vistulian at Zgierz-Rudunki in the Łódź Plateau (in Polish with English summary). Acta Geographica Lodziensia, 53.

Jewtuchowicz S. (1967) Origin of the Warsaw-Berlin Pradolina between rivers Ner and Moszczenica (in Polish with English summary). Prace Geograficzne Instytutu Geografii PAN, 62.

Jewtuchowicz S. (1970) Evolution of land-forms in the region of Łęczyca since the Middle-Polish Glaciation (in Polish with English summary). Prace Geograficzne Instytutu Geografii PAN, 85.

Kabata-Pendias A., Pendias H. (1993) Biogeochemia pierwiastków śladowych. Wydawnictwo Naukowe PWN, Warszawa.

Kamiński J. (1993) Late Vistulian and Holocene transformation of the Moszczenica River valley as a result of changes of the natural environment and man activity (in Polish with English summary). Acta Geographica Lodziensia, 64. 
Klajnert Z., Piechocki A. (1972) The Upper-Pleistocene deposits with molluscan fauna in the Bobrówka Valley near Łowicz (in Polish with English summary). Folia Quaternaria, 40: 1-36.

Klatkowa H. (1990) The occurrence of the Eemian organic deposits and remarks on the paleomorphology of Central Poland at the Wartanian decline and during the Eemian period (in Polish with English summary). Acta Geographica Lodziensia, 61: 7-17.

Klatkowa H. (1991) The results of grain abrasion analysis of the selected Quaternary sediments of Central Poland (in Polish with English summary). In: Geneza, litologia i stratygrafia utworów czwartorzędowych (ed. A. Kostrzewski). Wydawnictwo Naukowe Uniwersytetu im. Adama Mickiewicza w Poznaniu, Seria Geografia, 50: 277-287.

Klatkowa H. (1993) Some features of the Warta glacigenic deposits in Middle Poland (in Polish with English summary). Acta Geographica Lodziensia, 65: 99-140.

Klatkowa H., Balwierz Z. (1990) A closed depression with the Eemian flora at Modlna near Łódź (in Polish with English summary). Acta Geographica Lodziensia, 61: 39-49.

Klatkowa H., Winter H. (1990) The Eemian Integlacial at Ostrów near Grabica (in Polish with English summary). Acta Geographica Lodziensia, 61: 59-68.

Kłysz P. (1981) Morphogenesis of a sequence of marginal forms in the surroundings of Konin, Koło and Turek (in Polish with English summary). Wydawnictwo Naukowe Uniwersytetu im. Adama Mickiewicza w Poznaniu, Seria Geografia.

Kotarbiński J., Krupiński K.M. (1995) Eemian Interglacial deposits in Studzieniec and Babiec Piaseczny near Sierpc (central Poland) (in Polish with English summary). Przegląd Geologiczny, 43: 565-571.

Kowalkowski A. (1988) Wiek i geneza gleb. In: Przemiany środowiska geograficznego Polski (ed. L. Starkel): 45-85. Zakład Narodowy im. Ossolińskich, Wrocław.

Kozarski S. (1981) Stratigraphy and chronology of the Vistulian in Great Poland Lowland (in Polish with English summary). PAN, Oddział w Poznaniu, Geografia, 6.

Lindner L., Marks L. (2012) Climatostratigraphic subdivision of the Pleistocene Middle Polish Complex in Poland (in Polish with English summary). Przegląd Geologiczny, 60: 36-45.

Mackereth F.J.H. (1966) Some chemical observations on post-glacial lake sediments. Philosophical Transactions of the Royal Society, London, B, 250 (765): 165-213.

Malkiewicz M. (2002) The history of vegetation of the Eemian integlacial in the Great Polish Lowland. Acta Societatis Botanicorum Poloniae, 71: 311-321.

Mamakowa K. (1988) Pollen stratigraphy of Eemian and adjoining glacial deposits based on continuous sequences in Poland. Bulletin of the Polish Academy of Sciences, Earth Sciences, 36: 299-307.

Mamakowa K. (1989) Late Middle Polish Glaciation, Eemian and Early Vistulian vegetation at Imbramowice near Wrocław and the pollen stratigraphy of this part of the Pleistocene in Poland. Acta Palaeobotanica, 29: 11-176.

Manikowska B. (1993) Mineralogy and abrasion of sand grains due to Vistulian (Late Pleistocene) aeolian processes in Central Poland. Geologie en Mijnbouw, 72: 167-177.

Marks L. (2005a) Pleistocene glacial limits in the territory of Poland. Przegląd Geologiczny, 53: 988-993.

Marks L. (2005b) Pleistocene river system in the southern peribaltic area as indication of interglacial sea level changes in the Baltic Basin. Quaternary International, 130: 43-48.

Marks L., Pochocka K. (1999) River valleys of the Eemian Interglacial in central Poland. Geological Quarterly, 43 (2): 163-168.

Meng S., Börner A., Strahl J., Thieke H.U. (2009) Bio- and lithostratigraphical investigations of Eemian fluviolacustrine sediments and tills from the Lower Peene Valley (NE Germany). Polish Geological Institute Special Papers, 25: 37-48.

Mirosław-Grabowska J., Niska M., Sienkiewicz E. (2009) Evolution of the paleolake at Ruszkówek (central Poland) during the Eemian Interglacial based on isotope, cladoceran and diatom data. Journal of Paleolimnology, 42: 467-481.
Mojski J.E. (2005) Ziemie polskie w czwartorzędzie. Zarys morfogenezy. Państwowy Instytut Geologiczny, Warszawa.

Mycielska-Dowgiałło E. (1995) Selected textural features of deposits and their interpretation value (in Polish with English summary). In: Badania osadów czwartorzędowych (ed. E. Mycielska-Dowgiałło): 220-235. Wyd. Wydziału Geografii i Studiów Regionalnych Uniwersytetu Warszawskiego.

Noryśkiewicz B. (1978) The Eemian Interglacial at Nakło on the River Noteć (N Poland) (in Polish with English summary). Acta Palaeobotanica, 19: 67-112.

Noryśkiewicz B. (1999) Palynology of biogenic sediments of the Eemian Interglacial at Krzyżówki near Koło, central Poland. Geological Quarterly, 43 (1): 107-111.

Nowacki K. (1995) Objaśnienia do Szczegółowej Mapy Geologicznej Polski w skali 1:50 000, arkusz Dąbie. Państwowy Instytut Geologiczny, Warszawa.

Nowaczyk B., Tobolski K. (1980) Remarks on Late-Glacial limnic sediments accumulated in the water environment (in Polish with English summary). Badania Fizjograficzne nad Polska Zachodnią, 33: 65-78.

Okruszko H. (1976) Zasady rozpoznawania i podziału gleb hydrogenicznych z punktu widzenia potrzeb melioracji. Biblioteka Wiadomości, Instytut Melioryzacji i Użytków Zielonych, 52: 7-53.

Pawłowski D. (2011) Evolution of an Eemian lake based on Cladocera analysis (Konin area, Central Poland). Acta Geologica Polonica, 61: 441-450.

Petera J. (2002) Vistulian valley deposits in the Uniejów Basin and their palaeogeographical significance) (in Polish with English summary). Acta Geographica Lodziensia, 83: pp. 164.

Racinowski R., Szczypek T., Wach J. (2001) Prezentacja interpretacja wyników badań uziarnienia osadów czwartorzędowych. Wydawnictwo Uniwersytetu Śląskiego.

Reimann C., Arnoldussen A., Boyd R., Finne T.E., Koller F., Nordgulen R., Englmaier P. (2007) Element contents in leaves of four plant species (birch, mountain ash, fern and spruce) along anthropogenic and geogenic concentration gradients. Science of the Total Environment, 377: 416-433.

Skompski S. (1983) Eemian interglacial molluscans from Żmigród upon the Barycz River (in Polish with English summary) Kwartalnik Geologiczny, 27 (1): 151-187.

Stankowski W., Krzyszkowski D. (1991) The Quaternary stratigraphy of the Konin area (in Polish with English summary). In Przemiany środowiska geograficznego obszaru Konin - Turek (ed. W. Stankowski): 11-31. Inst. Badań Czwartorzędu Uniwersytet im. Adama Mickiewicza w Poznaniu.

Stankowska A., Stankowski W. (1988) Maximum extent of the Vistulian Ice Sheet in the vicinity of Konin, Poland: a geomorphological, sedimentological and radiometric evidence. Geographia Polonica, 55: 141-150.

Stankowski W., Tobolski K. (1981) Eemian peat and lacustrine deposits from the Kazimierz exposure of the brown coal mine Konin - preliminary report (in Polish with English summary). Badania Fizjograficzne nad Polską Zachodnia, 34: 171-178.

Szałamacha G., Skompski S. (1999) Biogenic sediments of the Eemian Interglacial at Krzyżówki near Koło, central Poland. Geological Quarterly, 43 (1): 99-105.

Szeroczyńska K. (1998) Cladocera as information source in studies of lake sediments (in Polish with English summary). Studia Geologica Polonica, 112: 9-28.

Szeroczyńska K., Sarmaja-Korjonen K. (2007) Atlas of subfossil Cladocera from Central and Northern Europe. Friends of Lower Vistula Society, Świecie.

Tobolski K. (1986) Paleobotanical studies of the Eemian interglacia and Early Vistulian at Władysławów in the vicinity of Turek (Preliminary report). Quaternary Studies in Poland, 7: 91-101.

Tobolski K. (1991a) Biostratigraphy and palaeoecology of the Eemian Interglacial and the Vistulian Glaciation of the Konin region (in Polish with English summary). In: Przemiany środowiska geograficznego obszaru Konin - Turek (ed. W. Stankowski): 
45-87. Wydawnictwo Naukowe Uniwersytetu im. Adama Mickiewicza w Poznaniu.

Tobolski K. (1991b) Eemian and Vistulian biostratygraphy of Great Poland-Kujawy Lowland (in Polish with English summary). In: Geneza, litologia i stratygrafia utworów czwartorzędowych (ed. A. Kostrzewski). Uniwersytetu im. Adama Mickiewicza w Poznaniu, Seria Geografia, 50: 573-583.

Trzmiel B. (1996) Objaśnienia do Szczegółowej Mapy Geologicznej Polski w skali 1:50 000, arkusz Turek (550). Państwowy Instytut Geologiczny, Warszawa
Turkowska K., Forysiak J., Petera J., Miotk-Szpiganowicz G. (2004) A Warta River system during the Younger Dryas in the Koło Basin (Middle Poland). Questiones Geographicae, 23: 83-107.

Whiteside M.C. (1970) Danish Chydorid Cladocera: modern ecology and core studies. Ecological Monographs, 40: 79-118.

Widera M. (1998) Palaeomorphological and palaeotectonical evolution of the Konin Elevation (in Polish with English summary). Geologos, 3: 55-103. 